\title{
THE SEARCH FOR NEW MEASURES IN ORGANISATIONAL COMMUNICATION: A SYSTEMATIC LITERATURE REVIEW
}

\author{
Gibriel Badjie $^{1}$, Armanu Thoyib ${ }^{2}$, Djumilah Hadiwidjojo ${ }^{3}$, Ainur Rofiq ${ }^{4}$ \\ ${ }^{1}$ Doctoral student, ${ }^{2,3,4}$ Promoter \& Lecturer, Department of Management, Faculty of Economics \& Business, University of \\ Brawijaya, Malang, Indonesia \\ gbadjie@utg.edu.gm, armanuthoyib@gmail.com, Djumilah.zain@yahoo.com,rofiq@ub.ac.id
}

Article History: Received on $18^{\text {th }}$ February 2019, Revised on $17^{\text {th }}$ April 2019, Published on $02^{\text {nd }}$ August 2019

\begin{abstract}
Purpose of the study: Communication is a central pillar in organisation, yet little genuine communication takes place in the organisation. The purpose of the paper is to craft communication model that promotes routine information availability and accessibility by simplifying the approach to organisational communication through the leadership level, functional level and operational level.
\end{abstract}

Methodology: The study applied systematic literature review (SLR) or systematic research synthesis (SRS) as the approach to gather data, analyse to address the research query. The study method embraces the definition of SLR by Rousseau et al. (2008). The conditions for literature search electronically was done through multiple journal sites. The gathered published material dated between 1961-2018.

Main Findings: The paper put forward three propositions to establish the argument for organisational communication. The findings show that there is no definitive agreement what constitute organisational communication as it is given many names like internal communication, employee communication, corporate communication etc. There is total lack of structural approach to organisational communication.

Applications of this study: The paper refocuses organisational communication towards a three-tier approach and challenges leadership to communicate in tandem with managerial roles as purported by Mintzberg in order to give prominence to organisational communication.

Novelty/Originality of this study: The paper introduces three new dimensions as measures of organisational communication with a new perspective on leadership communication, where Mintzberg's managerial roles were used as reference for leadership communication responsibility which is missing in today's organisation. The new measures of organisational communication are leadership level, functional and operational level.

Keywords: Communication, Communication climate, Organisational communication, Organisational climate

\section{INTRODUCTION}

The quest to charge and make organisational communication layered and targeted in a bid to create conditions for mutual understanding and partnership is stressed by the need for routine communication in the new wave of social media proliferation within organisation. Good communication in an organisation produce positive emotions and energy as it resonates with the employee's healthy psychological wellbeing while bad communication produces negative emotions and energy that create dissonance in the employees thus psychologically stressful to organisational atmosphere. Good communication is fundamentally effective to management. "Communication in the organisation always take a contingency approach since the effectiveness of communication depends on environmental constrains and parties to the communication relationship". The evolution and enhancement of organisational communication due to the proliferation of technology aided medium of communication makes it imperative to reflect upon the fit concept to address the specific needs of people in a communication relationship for greater good (Gilley, Gilley \& McMillan, 2009).

There are many literature materials relating to organisational communication but there is a total lack of consistency among many scholars as to what does organisational communication really represent. Some researchers equate organisatinal communication to internal communication or employee communication, defined to buffer internal interactions and engagements e.g (Berger, 2008; Cutlip, Center \& Broom,2006). Others also refers to organisational communication as

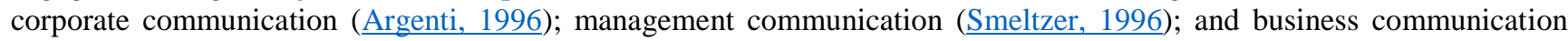
(Reinsch, 1996).

According to Frank \& Brownell, (1989), who dismiss any similarity between internal communication and organisational communication. They portrayed organisational communication as a field of study and practice, not internal communication or employee communication as part of integrated corporate communications. Organisational communications is bigger and broader in scope and focus compared to internal communication or employee communication. They claimed that some narrowly defined organisational communication as approoriate for internal communication. How are the two different? How to invoke flexibility in the organisation to reduce ambiguity in communication? The purpose of the paper is to craft communication model that promotes routine information availability and accessibility by simplifying the approach to organisational communication through the leadership level, functional level and operational level. 


\section{LITERATURE REVIEW}

\section{Communication}

Communication is one of the most dominant and important activities in organisation (Harris \& Nelson, 2008). Berger, (2008) "relationship grows out of communication and the functioning and survival of organisations is based on effective relationship among individuals and groups. Communication help individuals and groups to coordinate activities to achieve goals, and it is vital in socialisation, decision making, problem solving and change management processes". Organisational capabilities are developed and enacted through "intensely social and communicative processes" (Jones et al., 2004).

Research indicates that top management communication is directly related to organizational commitment (Postmes, Tanis \& de wit, 2001), whereas other research indicates that top management communication is related to organizational commitment indirectly through its relationship with two mediators: organizational efficacy and person-organization fit (Vuuren, 2008). "Communication involves an observable interchange of information and subtle interaction of power, attitude and values" (Loxley, 1997).

\section{Communication climate}

In their report Putnam \& Cheney, (1985) defined "communication climate" as "atmosphere in an organisation regarding accepted communication behaviour". Key factors in the communication climate include horizontal information flow Bartel, Pruyn, De Jong, Inge, (2007), openness, vertical information flow and reliability of information. A distinction can be made between supportive and defensive communication climate, den Hoff \& de Rider, (2004), where supportive communication climate is characterised by open exchange of information, accessibility to co-workers, confirming and cooperative interactions and an overall culture of sharing. According to Buzzaelli \& Stohhl, (1999), communication climate is crucial when creating an effective organisation. A frequently used definition of communication climate is that of (Dennis, 1974). Communication climate thus be defined as the perception of employees about the quality of the mutual relations and the communication in an organisation (Guzley, 1992).

Dennis (1974) defines the concept of communication climate and related dimensions and posits that an ideal communication climate consists of eight dimensions; Supportiveness, openness and candour, participative decision making, confidence and credibility, high performance goals, information adequacy, semantic information difference, and communication satisfaction (Bartels et al..,2006).

\section{Organisational communication}

According to Welch \& Jackson, (2007) organisational communication is mostly labelled as a field of study and looks at communication and organisational behaviour and is described in various ways. Welch \& Jackson (2007) stressed that organisational communication focuses on symbolic use of language, how organisation functions and what goals to achieve. To Miller, (1999) organisational communication is a discipline that focuses on the context of organisation and their communication processes.

Cheney \& Christensen, (2001) argued that internal and external communication no longer exist as separate communication entities and the two are heavily integrated within the context of organisation. Organisational communication has shifted to one of that integrate external and internal communication with blurred boundaries between the two. This paper first endeavours to create an explanation of how internal and external communication are integrated under organisational communication. Secondly the paper create new dimensions and measures of organisational communication to help draw and bring communication closer to parties in a routine manner. Third to use the new measures to establish the the scope and focus of organisational communication.

\section{Organisational climate}

The more complex organisations become, the more communication is needed and the greater the likelihood of it being inappropriate, misinterpreted or even at breaking points (Gilley, Gilley \& McMillan, 2009). Management is primarily responsible for creating a climate that responds to environment positively and benefits the organisation, service users and staff. Good communication cannot stand alone and cannot guarantee to ensure such climate, but it cannot be achieved without routine communication (Jablin, 1980). Climate is synonymous to atmosphere within a given environmental setting; "organisational climate is the aggregate of psychological climate which are perceptions of individuals about their work environment" (Field \& Abelson, 1982). Employees' perception is strongly influenced by psychological and social benefits within the organisation.

Employee behaviour in organisations is a result of their personal characteristics as well as their environment in which they perform. Employees' job attitudes and behaviours are affected by a wide range of organisational characteristics and social relationships, which form the grounding for employees' perceptions of their working environment (Williams et al., 2018). According to organisational behavioural theorists, behaviour in the organisation is contained in individual, group and structure. Similarly, organisational communication also follows the same similar pattern to define individual, group and structural behaviour within the organisation. 
Castro \& Martins (2010), organisational climate include; trust, training \& development, transformation \& diversity, job satisfaction, leadership, employee wellness, communication, performance management, renumeration \& reward, teamwork, work involvement and image of the organisation.

\section{Conceptual Development}

\section{Organisational Communication Measures (OCM)}

Today there is no shortage of literature regarding communication in organisation yet there is little communication that takes place between management and employees. Most of the researches about communication in the organisation use a generalized approach to organisational communication, mistakenly associated with traditional communication processes, employee or internal communication which mandates to feed the employees on ways to support the organisation as championed by communication Gurus and practitioners. Therefore, to enable employees to do what is expected of them, deserves to access the much-needed information as a resource to translate into reality in a well-defined organisational communication setting.

Organisational communication (OC) as a concept within the framework of this paper take its root from organisational climate and communication climate. According to Burke \& Litwin (1992) organisational climate is a set of measurable properties of the work environment which are perceived directly or indirectly by people who live and work in the environment and assumed to influence their motivation and behaviour. Putnam \& Cheney (1985) addresses communication climate as "an atmosphere in an organisation regarding accepted communication behaviour" which can affect the entire organisation.

In creating the new measures for organisational communication, the paper integrates the ideas of organisational climate and communication climate. The objective of creating this new measure of organisational communication is to portray a communication situation that merges both the micro and macro factors to help to position communication in organisational efforts. This new organisational communication measures (OC) identifies three levels of organisational communication. Each level is different in each way in terms of communication behaviours relating to the other levels of behaviour in the organisation, i.e. individual, group and organisation (structure).

1. The leadership level relates more to decision making and strategic goals of the organisation in positioning communication at the centre of efforts to achieve organisational success. At this level, information or communication is meant to define the vision, uplift spirit, morale and hopes of the stakeholders.

2. The functional level relates more to building good working relationship between the organisation and its constituents e.g. management-employee relationship, organisation-stakeholders or shareholder or investor relationship, organisation-partners relationship. It is responsible to enhance the image and reputation of the organisation by building collaborative strategic alliances and mutual working relationships.

3. The operational level is the most active and engaging to the employees. This level relates more to the employees compared to the leadership and functional levels. This level gives and defines the processing of the information given to employees to translate into reality. It is the input-throughput-output oriented conversation cycle within the organisation which requires more communicative interaction and attention involving employees. The operational level simply is linked to messaging or transfer of information but is also recognised as characterizing the attitude and behaviours of the employees. This level also deals with the disposal of organisational outcomes to the outside through marketing efforts.

Organisational communication is defined as the condition within the leadership, functional and operational level of the organisation that create a supportive or defensive communication atmosphere strategically placed in ways that powers and add value to the organisation.

\section{METHODOLOGY}

This study applied the systematic literature review (SLR) or systematic research synthesis (SRS) as the approach to gather data to make sense for the paper. The study embraced the definition of Rousseau et al., (2008) "a research synthesis is the systematic accumulation, analysis and reflective interpretation of the full body of relevant empirical evidence related to a question". Accordingly, "the motives for undertaking a research synthesis include scientific discovery and explanation to improve management practice guidelines and for making public policy".

The objective of the research investigation is to gather data that examine communication in organisational setting. Since the goal of the paper is to invoke flexibility in the organisation to reduce ambiguity in communication. The approach of the synthesis entailed extensive, general and open-ended searches of relevant databases appropriate to focus on the research question (i.e. how to invoke flexibility in the organisation to reduce ambiguity in communication?). the conditions for data collection searches were limited to the following;

1. Keywords, I searched based on defined keyword which include 'communication'; 'communication climate'; 'organisational communication'; 'organisational climate'.

2. The search include data published either as journal article, book (e-book or hard copy) or chapter/s. 
3. The published data sets were identified through electronic data base accessible through many search sites (e.g. University library system). Also, hard copies of books were accessible through the University library.

4. General electronic searches were also conducted using google scholar, ResearchGate, Emerald, ScienceDirect, Sage Publications, Elsevier, Scopus, Web of Science etc.

5. There is no limitation to date of publication materials, a total of 51 published materials were gathered dated between 1961-2018 including journal articles, books and chapters.

\section{DISCUSSION / ANALYSIS}

The three levels of organisational communication (OC) unite both micro and macro measures to help improve understanding of organisational phenomena. The key commonality among the three level is that each level has both internal and external communication responsibilities.

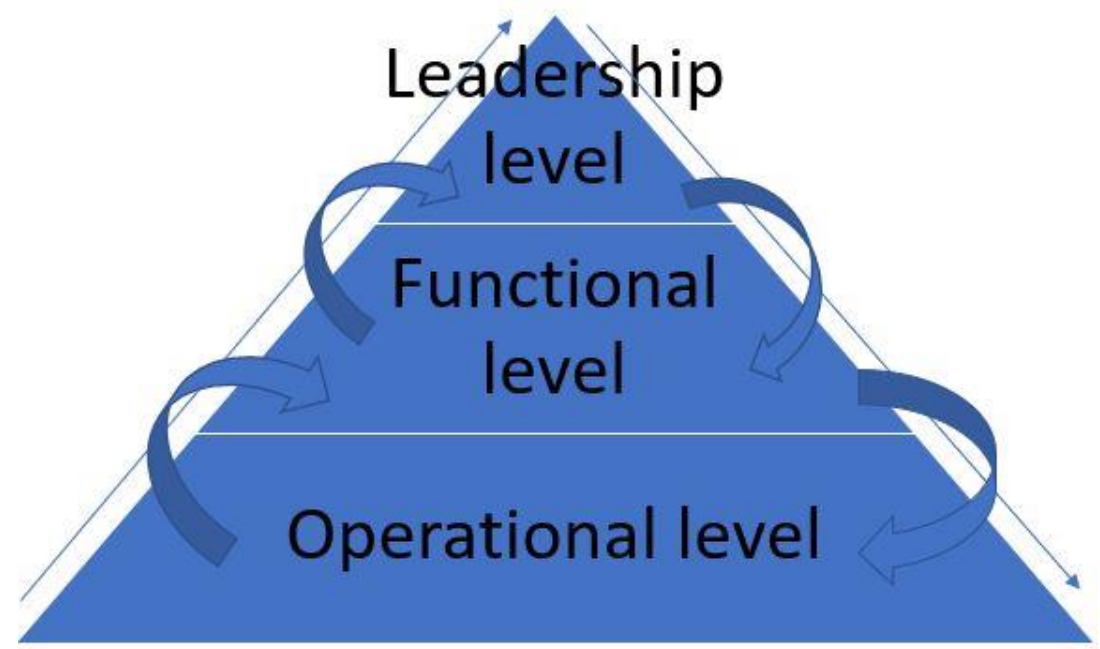

Figure 1: Levels of Organisational Communication

The flow of information and the direction of communication is defined by the situation at hand. Communication or information from the operational level going upwards becomes narrower towards the top because it concerns or affects a small number of recipients as targeted. Communication or information flow from the leadership level going downwards towards the bottom, lower level based of the pyramid becomes wider because it affects and concern many people. Therefore, the communication needs to be segmented and targeted to help achieve organisational goals. The functional level sits at the centre and serve as a buffer to create a balance in maintaining a common ground provided that the functions are independent recognised.

\section{Leadership level}

Leadership communication has the power to move mountains, heal wounds, excites people with zeal to positive action yet leadership communication failures can have negative effect on performance. Leadership communication today must be measured in a context to fit the diverse employees or situation as reflected by the contingency ideology. Leadership communicate when it matters most because, when leaders communicate, their rhetoric goes with policy implication. Effective communication can brand a leader, enhance his reputation and boost his image as trusted and reliable. Leader's communication can give him credibility and respect which is earned not given. Leadership failure to communicate can create suspension, suspicions, anxiety, fear, confusion and leads to anarchical destructive behaviours for the organisation thus shrinking and lowering organisational performance. The leadership level of communication is created using Mintzberg's (1971) managerial roles as these roles clearly defined leadership communication responsibilities.

In his research, Mintzberg (1971) asserts that the major part of managerial work is characterised by "coordinating and planning". In Mintzberg's study of chief executives of five middle to large size American organisations both for public and private, identified ten managerial roles akin to all types of organisations and these roles are grouped into three categories namely; interpersonal role, informational roles and decisional roles. Each of these roles is loaded with communication capability, communication skills to enable the management to transcend all odds to get the organisation moving.

\section{Interpersonal Roles}

This role consists of figurehead role, leader role and liaison role. This role requires interpersonal communication and interpersonal skills, the ability to pull others towards you, the ability to give and get attention. Interpersonal communication is the most difficult part of communication which many find challenging to master as it is accompanied by 
the individual's personality. The individual's personality is the total of who he/she is, in terms of manifestation. Personality is built upon the individual from different sources that to a large extent help the person in relating to others different in different situations. The five big traits are the perfect characteristics that a leader in interpersonal communication needs on board his/ her DNA to succeed. According to Barrick \& Mount, (1991), big five personality traits include extroversion, agreeableness, conscientiousness, emotional stability and openness to experience.

The interpersonal role of a leader expects the leader to have visibility among many to be recognised to have clout and influence. Interpersonal communication is the only way leaders can remain visible and tall among many people with star qualities unmatched by any. Interpersonal communication is difficult because it requires positive emotions and often challenged by peoples' difference rather than what binds them together in any given situation. It is mostly infested with misunderstanding rather than lack of understanding. It is only through effective interpersonal communication, leadership can work with or through people to achieve organisational goals. It is a face-to-face interaction, two-way communication that strongly endorsed the leader especially when handling sensitive issues, managing a large-scale change in the organisation.

\section{Informational Role}

Informational role which consists of monitor role, disseminator role, and spokesperson role hailed the leader as a container of data and information that needs to be shared with others who needs the information more to enable them to do their part of the work to enhance organisational performance. Information is a source of data and the act of sharing data becomes communicative, so communication is loaded with wisdom from those who access and share the information to those who receive to interpret it. The wisdom in information communication lies in the way the information is communicated, explained and put into context to serve the needs of the organisation and its people. This is only possible in an open climate, but closed climate tends to hoard the information as a source of power for some.

The leader as a spokesperson makes him/her a buffer or a bridge in engaging the diverse stakeholder interests in organisation both inside and outside. As a spokesperson, he has a wealth of institutional memory and knowledge. People would always want to hear from the leader ("horse's mouth") which carries much weight in the eyes of many compared to when such leadership responsibility is delegated. The leadership as a key spokesperson for the organisation especially in moments of dramatic changes, the leader's communication goes with policy and carries weight for implementation.

\section{Decisional Role}

This role completes the leader-employee interaction relationship communicatively. Decision making is a distinguishing factor to differentiate managers and non-managers and the quality of decisions managers or leaders make determines their effectiveness.

The decisional role is a factor of change for the leader, employees and the entirety of the organisation. The entrepreneurial role of the leader challenges the leader to take responsibility for bringing about change in the organisation (Mintzberg, 1971). The entrepreneurial role requires critical thinking and a wealth of creativity to think outside the extraordinary to look for problems or opportunities and then take a measured move to initiate projects or programs to take the better of it. Leader's decision-making framework is based on either to address problems or to take advantage of an opportunity. Therefore, the leader is challenged by both within and outside forces that may serve as detractors to make fail in pursuit of the main goals. But the leader must stand firm and unshakeable to handle disturbances as detractors to the process of change effort to exert maximum control.

As part of the decisional role, the leader allocates resources for the implementation of all the decisions made to the parties who have a stake in the decision. Deciding who gets what, who does what and under which context for both internal and external constituents of the organisation. The leader plays a negotiator role, where he resides over and takes charge whenever the organisation enters crucial negotiation both within and outside the organisation. The presence of the leader is required because he/she has the information and the authority to make the 'real time' decisions that difficult negotiation demands (Mintzberg, 1971). This has everything to do with credibility and extend to which employees will trust, commit to and follow leaders, as Maguire \& Pitceathly, (2002) said, "Actions lie louder than words".

Proposition 1: The more routinely leadership communicates in line with roles, the greater the ability to shape the attitudes and behaviours of employees to profit organisation. Berger (2008), the action of leaders at all levels must match their words. The communication style of leaders should invite open, ongoing and transparent discussion so that people are willing to voice their opinions and suggestions.

\section{Functional level}

Functional communication has a dual career, internal and external communication, it provides important stakeholders with important information about their jobs, organisation, environment and each other. Communication can help motivate, build trust, create shared identity and spur engagement; it provides a way for individuals to express emotions, share hopes and ambitions, celebrate and remember accomplishments (Berger, 2008). Communication is the basis for individuals and groups to make sense of their organisation, what it is and what it means (Jones et al. 2004). A recognition of 
communication strategic position will always guide organisation's initiatives in a most fitting way to putting all on the same wave length in terms of knowing what to do. The recognition of the value of communication helps to guide leaders with "what to say and how to say it" to produce long term profitable and sustainable organisation.

Communication as a function within the organisation serves as a buffer and maintenance capability to hold the different departments and their different activities on purpose through coordination. Gay, Mahoney, \& Graves, (2005), internal communication is the most fundamental driver of business performance. Smidts, Pruyn \& Van Riel (2001), asserts that positive communication climate and effective employee's identification with their organisations contributes to an organisation's financial performance and sustained success. Likert, (1961), believes that a systems organisation approach is characterized by multi-directional communications and participatory style and structure, would spur productivity gains and reduce absenteeism and turnover.

Communication as a function relates to Public relations or Corporate Communications as communication professionals are mandated to engage both internal and external constituents. Public relations excellence theory is grounded in a systems perspective (Dozier \& Grunig, 1995); (Grunig \& Hunt, 1984). The role of public relations is to help organisations develop and maintain mutually beneficial relationships with internal and external stakeholders through excellent communications.

Proposition 2: The more decentralised the layers of communication, the greater the effectiveness of the organisation. Berger (2008), evidence demonstrate that effective internal communications helps increase employee job satisfaction, morale, productivity, trust and learning, improve communication climate and relationships with publics enhance quality, revenue and earnings. Employee's satisfaction with communication in the organisations is linked to organisational commitment, productivity, job performance and satisfaction and other significant outcomes (Castro \& Martins, 2010).

\section{Operational level}

This level of organisational communication is concern with structures within the organisation that define the flow of information or the direction of communication within the organisation in teams, units, divisions and departments. The communication engagement is mostly a top-down approach and one-way centred Deetz \& Putnam, (2001), communication as a process relates to organisational capability. Deetz \& Putnam, (2001) sees internal communication as a container in which communication occurs and as a "way to describe and explain the organisation to the employees". The communication as a process is the combination of people, messages, meanings, practices and purpose Erdem, Ozen \& Atsan (2003) and it is the foundation for modern organisations. This level is highly structural and lived on formal communication planning and implementation as the main feed of the organisation. Formal communications are grounded in the sender and receiver's needs and concern (Berger, 2008).

The unique quality of communication in this level is to serve as a conduit for messaging link or medium to share or transmit information to the employees, who needs it to do their jobs. The organisational communication at the stage relates to the supportiveness or defensiveness of the communication networks, a network represents how communication flows in an organisation. Networks can be formal or informal (Burton, Grates, \& Learch, 2013). The informal communication network moves along unofficial paths (grapevine, which is fast and multidimensional) and includes rumours, opinions, aspirations and expression of emotions. Williams et al. (2018), evolving organisational structures and technologies create opportunities for new and conflicting communication flows. The new social media networking is keenly exploited to serve the interest of a few rather than the collective interest.

According to McLuhan, (1964), today’s organisation and their employees have access to many communication channels. Selecting the most appropriate medium or media is an important issue for professional communicators once they have determined objectives, and strategies, assessed relevant audiences and constructed messages. Perhaps one made this point more strongly than, McLuhan who claimed that "the medium is the message". He argued that each medium, independent of content, engages receivers in different ways and affects the scale and pace of communication.

Proposition 3: The more engaged and involved employees in communication processes, the greater the satisfaction, commitment and identity to serve the organisation. Studies regarding the effectiveness of communication flows often revealed employee's dissatisfaction with both downward and upward communications (Cutlip, Center, \& Broom, 2006). Organisational leaders develop strategies to achieve objectives, construct relevant messages and then transmit them through diverse channels to stimulate conversation and action with the employees (Berger, 2008).

\section{CONCLUSION}

Organisational communication can be empowered through a genuine leadership communication as obligated, but today routine leadership communication does not take place because the leadership is too busy and quite often delegate that responsibility to others. Leadership delegation communication responsibility is unproductive to the health of the organisation in terms of performance. Research indicates that top management communication is directly related to organizational commitment, Postmes et al. (2001). 
Leadership delegation of communication can defraud the leadership from genuine connection with employees. Leadership communication is the face and image of the organisation, so if the leadership responsibility is delegated, such person becomes the new face and image of the organisation.

How can one avoid such a situation? The simple solution is for leadership to communicate to the employees in line with his/her managerial roles e.g. interpersonal role, informational role and decisional role. Every organisation must task itself as part of policy for the leadership to always fall on the ground to communicate with the employees once every week, or every two weeks, or once every month, or every three months or once every six months or once in a year. This will help the leadership to establish how his /her communication reflects the attitude and behaviours of the employees directly without mediation.

Critics will say that the approach and assumptions of the new organisational communication approach is too ambitious and not workable. Today we are in the age of information and communication proliferation with the use of social media platforms as a source of information and communication platform. The social media platform for information communication has become a platform for deception and propaganda as the new norm. So, if the leadership communication to employees is not aggressive, segmented, targeted and routine, meaning the leadership surrendering that mandate to the outside source to shape the perception of the narrative, Lombardi (2015). The new approach to organisational communication will be linked to HR outcomes e.g. job satisfaction, job involvement, job engagement, employee commitment, OCB, etc.

\section{LIMITATION AND STUDY FORWARD}

The ideas contained in this paper will no doubt add value to organisational communication designed to empower employees to contribute to organisational performance. The thoughts of the paper are drawn from both the organisational and communication perspective based on a review of related literature and as such it requires future research to see how the ideas will reflect in real organisational settings practically.

The paper also proposed leadership to voluntarily and willing surrender some control to make sure organisational communication becomes routine, structured and layered to reflect the existing situation but there is a limitation to leadership benevolence in terms of change of status-quo.

\section{ACKNOWLEDGEMENT}

I am greatly indebted to the University of The Gambia as the sole sponsors of my Doctoral degree programme in Management. My special thanks and appreciation go to Brawijaya University, department of Management, Faculty of Economic and Business for the psychological support. A humble thanks to my supervisory team for the guidance. I valued their collective wisdom, Prof. Armanu Thoyyib, Prof. Djumilah Hadiwidjojo, Ainur Rofiq.

\section{REFERENCES}

Argenti, P. A. (1996). Corporate Communication as a discipline: Toward a definition. Management Communication Quarterly, 10(1), 73. https://doi.org/10.1177\%2F0893318996010001005

Barrick, C. A., \& Mount, M. K. (1991). The Big Five personality dimensions and job performance: A meta-analysis. Personnel Psychology, 44. https://doi.org/10.1111/j.1744-6570.1991.tb00688

Bartel, J. Pruyn, A. De Jong, M.; Inge, J. (2007). Multiple organisational identification levels and the impact of perceived external prestige and communication climate. Journal of Organisational Behaviour, 28, 173-190.

https://doi.org/10.1002/job.420

Berger. (2008). Employee Communication. http://www.instituteforpr.com

Bowen, S. (2006). Autonomy in communication inclusion in strategic management and ethical decision-making, a comparative case analysis. Journal of communication management, 10, 330-352.

https://doi.org/10.1108/13632540610714791

Burke, W., \& Litwin, G. (1992). A causal model of organisational performance and change. Journal of Management, 18, 523-545. https://doi.org/10.1177\%2F014920639201800306

Burton, K., Grates, G., \& Learch, C. (2013). Best-in-class practices in employee communicaation: Through the lens of 10 global leaders. www.instituteforpr.com

Buzzaelli, P., \& Stohhl, C. (1999). The redding tradition of organisational communication scholarship: W. Charles Redding and His Legacy. Journal of Communication Structures, 50, 324-336. https://doi.org/10.1080/10510979909388503 
Castro, M. L. \& Martins, N.(2010). The relationship between organisational climate and employee satisfaction in a South African Information and Technology organisation. SA Journal of Industrial Psychology, 36, 1-9.

http://www.scielo.org.za/scielo.php?pid=S2071-07632010000100006\&script=sci_arttext\&tlng=e

Cheney, G., \& Christensen, L. (2001). "Organisational identity linkages between internal and external communication". in Jablin, F. M. and Putnam, L. L. (Eds.). The New handbook of organisational communication. Thousand Oaks, CA: Sage.

Cutlip, S., Center, A. H., \& Broom, G. (2006). Effective Public Relations. Englewood Cliffs, New Jersey: Prentice-Hall.

Deetz, S. A., \& Putnam, L. I. (2001). Thinking about future communication studies. Communication Yearbook, Routledge.

den Hoff, B. V., \& de Rider, J. A. (2004). Knowledge sharing in context: the influence of organisational comitment, communication climate and CMC use on knowledge sharing. Journal of Knowledge Management, 8, 117-130. https://www.emerald.com/insight/content/doi/10.1108/13673270410567675/full/html

Dennis, H. S. (1974). A theoretical and empirical study of managerial communication climate in complex organisation. Purdue University Library.

Dozier, D. M., \& Grunig, J. (1995). Manager's guide to excellence in public relations and communication management. Mahwah, New Jersey: Lawrence Erlbaum Associates Inc.

Erdem, F., Ozen, J.\& Atsan, N. (2003). The Relationship between trust and team performance, Journal of work study, 52 (7), 337-340, http://dx.doi.org/10.1108/00438020310502633

Field, R. H., \& Abelson, M. A. (1982). Climate: A Reconceptualisation and proposed model. Human Relations Journal, 35, 181-201. https://doi.org/10.1177\%2F001872678203500302

Frank, A., \& Brownell, J. (1989). Organisational communication and behaviour: Communicating to improve performance. Orlando, FL: Holt, Rinehart \& Winston.

Gay, C., Mahoney, M., \& Graves, J. (2005). Best practices in employee communication. San Francisco: International Association of Business Communication.

Gibb. (1961). Defensive communication. Journal of Communication, 11, 41-49. https://doi.org/10.1111/j.14602466.1961.tb00344.x

Gilley, A., Gilley, J. W. \& McMillan, H. S. (2009). Organisational Change: Motivation, Communication and Leadership Effectiveness, Performance Improvement Quarterly, 21 (4), pp. 75-94. https://doi.org/10.1002/piq.20039

Graham, P. (1995). saying "No" to compromise; "Yes" to Integration. Journal of Business Ethics, 17, 1007-1013. https://doi.org/10.1023/A:1006011130627

Grunig, J. E., \& Hunt, T. (1984). Managing public relations. Rhinehart and Winston: CBS College Publishing.

Guzley, R. M. (1992). Organisational climate and communication climate: predicators of commitment to the organisation. Management Communication Quarterly, 5, 379-402. https://doi.org/10.1177\%2F0893318992005004001

Harris, T., \& Nelson, M. (2008). Applied Organisational communication: Theory and practice in a global environment. New York: Lawrence Erlbaum.

Hofhuis, J., van der Rijt, P.G.A. \& Vlug, M. (2016). Diversity climate enhances work outcomes through trust and openness in work group communication. Journal of Communication, 5, 714. https://doi.org/10.1186/s40064-016-2499-4

Jablin, F. M. (1980). Organisational Communication Theory and Research: An overview of Communication Climate and Network Research. Annal of the International Communication Association, 4, 327-347. https://doi.org/10.1080/23808985.1980.11923810

Jones, E., Watson, B., Gardner, J., \& Gallois, C. (2004). Organizational Communication: Challenges for the new century. Journal of Communication, 54(4), 722-750. https://doi.org/10.1111/j.1460-2466.2004.tb02652.x

Likert, R. (1961). new pattern of management. New york: McGraw-Hill.

Lombardi, G. (2015). 'Social media inside a large organisation in exploring internal communication: Towards informed employee voice, 3rd edition. London, Gower: K. Ruck (ed.). 
Loxley, A. (1997). Collaboration in Health and Welfare. London: Jessica Kingsley Publishers.

Maguire, P., \& Pitceathly, C. (2002). Key communication skills and how to acquire them. Clinical Review, 325, 697-

700. https://doi.org/10.1136/bmj.325.7366.697

McLuhan, M. (1964). Understanding Media: The extension of man. New York: McGraw-Hill.

Miller, K. (1999). Organisational Communication, 2nd edition. Belmont, CA: Wadsworth Publishing.

Mintzberg, H. (1971). Managerial work: Analysis from observation. Management Science Journal, 18, B97-B110.

https://doi.org/10.1287/mnsc.18.2.B97

Moran, T., \& Volkwein, J. (1992). The cultural approach to the formation of organisational climate. Human Relations, 45, 19-47. https://doi.org/10.1177\%2F001872679204500102

Perrin, T. (2003). Working today: Understanding what drives employee engagement. USA: The 2003 Towers Perrin Talent Report.

Postmes, T., Tanis, M. \& de wit, B.(2001). Communication and commitment in organisation: A social identity approach. Journal of Group Processes \& Intergroup Relations, 4, 227-246. https://doi.org/10.1177\%2F1368430201004003004

Putnam, L. L., \& Cheney, G. (1985). rganisational communication: Historical development and future directions. Southern Illinois University Press.

Reinsch, L. N. (1996). Business communication: Present, Past \& Future. Management Communication Quarterly, 10(1), 27. https://doi.org/10.1177\%2F0893318996010001003

Rousseau, D. M., Manning, J., \& Denyer, D. (2008). Evidence in Management and Organizational Science: Assembling the Field's Full Weight of Scientific Knowledge Through Syntheses. SSRN eLibrary. Retrieved from http://papers.ssrn.com/sol3/papers.cfm?abstract_id=1309606

Smeltzer, L. R. (1996). Communication within the managers' context. Management Communication Quarterly, 10(1), 5. https://doi.org/10.1177\%2F0893318996010001002

Smidts, A., Pruyn A. Th. H. \& Van Riel C. B. M. (2001). The impact external prestige on organisational identificationof employee communication and perceived. Academy Management Journal of, 44, 1051-1062.

https://doi.org/10.5465/3069448

Vuuren, M. (2008). Communication, sensemaking and change as a chord or three strands: Practical implications and research agenda for communicating organisational change. Corporate communications: An International Journal, 13(3), 349-359. https://doi.org/10.1108/13563280810893706

Welch, M., \& Jackson, P. R. (2007). Rethinking internal communication: A stakeholder approach. Corporate Communication: An International Journal, 12, 177-198. https://doi.org/10.1108/13563280710744847

Williams, N. J., Ehrhart, M. G., Aarons, G. A., Marcus, S.C., \& Beidas, R. S. (2018). Linking molar organisational climate and strategic implementation climate to Clinicians' use of evidence-based psychotherapy techniques:Cross-sectional and lagged analyses from a 2-year observational study. Journal of Implementation Science, 13, 85.

https://doi.org/10.1186/s13012-018-0781-2

Wren, D., \& Bedeian, A. (2009). The evolution of Management Thought. United States of America: John Wiley \& Sons Inc. 